JURNAL RESPONSIF, Vol. 2 No.1 Februari 2020, pp. 19 29

E-ISSN: 2685-6964

\title{
Pengembangan E-Helpdesk Support System Berbasis Web di PT Akur Pratama
}

\author{
Phitsa Mauliana ${ }^{1}$, Wildan Wiguna ${ }^{2}$, Abrian Yudha Permana ${ }^{3}$ \\ 1 Universitas Bina Sarana Informatika \\ e-mail: phitsa.phu@bsi.ac.id \\ 2Universitas Bina Sarana Informatika \\ e-mail: wildan.wwg@bsi.ac.id \\ 3 Universitas BSI \\ e-mail: abrianyudha100@gmail.com
}

\begin{abstract}
Abstrak
Helpdesk merupakan layanan yang menyediakan informasi dan dukungan bagi pengguna komputer di perusahaan. Organisasi yang memiliki investasi besar terhadap teknologi atau yang melayani banyak pengguna akhir terus mencari cara yang efisien untuk memberikan dukungan teknis. Biaya pemeliharaan untuk sistem lama dapat menjadi sangat mahal, serta pada titik tertentu akan menjadi lebih efektif untuk beralih ke sistem yang baru. PT Akur Pratama merupakan perusahaan ritel yang mengandalkan IT Support dalam melakukan pemeliharaan sistem dan helpdesk. Dari kegiatan observasi pada perusahaan tersebut ditemukan beberapa permasalahan yang harus dibenahi. Karyawan internal perusahaan kesulitan dalam mengajukan komplain ketika terjadi permasalahan teknis dengan sistem operasional kerjanya. Terdapat biaya operasional yang tidak sedikit pada pemeliharaan sistem serta lamanya penanganan teknis yang dilakukan oleh IT Support. Pada penelitian ini menggunakan metode development research, sehingga tujuan dari penelitian ini yaitu mengembangkan e-Helpdesk Support System berbasis web yang dapat membantu Service Desk untuk memantau pekerjaan IT Support beserta laporan komplain dari karyawan internal di PT Akur Pratama. Hasil penelitian menunjukkan bahwa sistem yang dibangun mampu menampung keluhan dari user client atau karyawan internal perusahaan sehingga memudahkan proses pengajuan komplain. E-Helpdesk Support System membantu pihak manajemen dalam menghemat biaya operasional serta mempercepat penanganan teknis oleh IT Support. Pengembangan sistem tersebut berhasil menyediakan fasilitas bagi Service Desk dalam memantau pekerjaan IT Support beserta perekapan laporannya di PT Akur Pratama.
\end{abstract}

Kata Kunci: e-Helpdesk Support System, IT Support, Pemrograman Web, PT Akur Pratama

\begin{abstract}
Helpdesk is a service that provides information and support for computer users, especially in companies. Organizations that have large investments in technology or who serve many end-users continue to look for efficient ways to provide technical support. Maintenance costs for old systems can be very expensive, and at some point, it will be more effective to switch to a new system. PT Akur Pratama is a retail company that relies on IT Support in carrying out system maintenance and support. From observations of activities in the company found several problems that must be addressed. Internal company employees have difficulty in filing complaints when there are technical problems with the work operational system. There is an operational cost that is not small for the maintenance of the system and the length of technical handling carried out by IT Support. This research using the development research method, therefore the purpose of this research is to build a web-based e-Helpdesk Support System that can help the Service Desk to monitor IT Support work along with complaints reports from internal employees at PT Akur Pratama. The results showed that the system built was able to accommodate complaints from user clients or internal company employees so as to facilitate the process of filing complaints. The e-Helpdesk Support System helps management save operational costs and accelerate technical handling with IT Support. The system development succeeded in providing facilities for the Service Desk in monitoring IT Support work along with the recording of its report at PT Akur Pratama.
\end{abstract}

Naskah diterima 28 Oktober 2019; direvisi 03 November 2019; diterbitkan 20 Februari 2020 
Keywords: e-Helpdesk Support System, IT Support, Web Programming, PT Akur Pratama

\section{Pendahuluan}

Helpdesk adalah layanan yang menyediakan informasi dan dukungan bagi pengguna komputer, terutama di dalam perusahaan. Metode manajemen helpdesk bervariasi dari satu jenis organisasi dengan organisasi yang lainnya. $\mathrm{Di}$ banyak perusahaan skala kecil, helpdesk hanyalah satu orang yang memiliki beberapa ide dalam menangani masalah pengguna dan pengguna dapat menghubunginya hanya melalui telepon. Di perusahaan yang lebih besar, helpdesk dapat terdiri dari sekelompok ahli yang menggunakan perangkat lunak khusus untuk melacak status masalah pengguna, menganalisis masalah, dan dengan demikian memberikan solusi untuk masalah tersebut (Akinnuwesi et al., 2014).

Biaya operasional helpdesk terbilang cukup mahal seperti metode dukungan teknis lainnya. Oleh karena itu, organisasi yang memiliki investasi besar terhadap teknologi atau yang melayani banyak pengguna akhir terus mencari cara yang hemat biaya untuk memberikan dukungan teknis (Beisse, 2014). Organisasi dapat melakukan pemeliharaan sistem secara internal, ataupun mempekerjakan pihak outsourching untuk melakukan pemeliharaan sistem bagi organisasi tersebut. Organisasi sering kali memiliki personel yang didedikasikan untuk pemeliharaan sistem. Biaya pemeliharaan untuk sistem lama dapat menjadi sangat mahal, serta pada titik tertentu akan menjadi lebih efektif untuk beralih ke sistem yang baru daripada memperbaiki dan memelihara sistem yang lama (Stair, 2017).

PT Akur Pratama (Yogya Group) merupakan perusahaan ritel modern yang mengandalkan sistem komputasi pada proses kerjanya. Pada perusahaan tersebut terdapat suatu sistem bisnis beserta infrastrukturnya yang digunakan pada berbagai jenis pengelolaan data seperti pergudangan, administrasi, keuangan, hingga penjualan. Kemudian jika terjadi permasalahan pada sistem tersebut, maka pihak manajemen menyediakan layanan dari departemen ITS (Information Technology Service) dengan beberapa divisi yaitu Helpdesk, Hardware Maintenance, dan Network Operation Center (NOC). Ketiga divisi tersebut bertugas menangani berbagai permasalahan teknis mulai dari perangkat keras, perangkat lunak, maupun jaringan komputer.

Dari hasil observasi yang telah dilakukan pada PT Akur Pratama ditemukan beberapa permasalahan yang harus dibenahi. Beberapa karyawan internal yang bekerja dengan sistem komputasi mengalami kendala komunikasi teknis dalam mengajukan komplain ketika terjadi permasalahan dengan perangkat operasional kerjanya. Manajemen dukungan teknis pada perusahaan tersebut mengeluarkan biaya operasional yang tidak sedikit dalam melakukan pemeliharaan sistem yang lama hingga banyaknya personel IT Support yang harus direkrut. Kemudian kelangkaan tenaga ahli yang sangat terampil pada bidang IT (Information Technology) menyebabkan lamanya penanganan permasalahan sistem yang dilakukan oleh IT Support. Penanganan tersebut sulit dipantau oleh Service Desk, serta tidak adanya perekapan laporan komplain dalam satu periode tertentu. Semua kendala tersebut dikarenakan belum adanya suatu sistem elektronik pendukung teknis yang disediakan oleh pihak manajemen dalam menampung keluhan dari karyawan internal perusahaan.

Electronic Helpdesk (e-Helpdesk) yaitu sistem digital yang digunakan untuk mengelola keluhan pengguna secara sistematis dan efisien di suatu organisasi. Kelangkaan tenaga ahli yang sangat terampil dalam berbagai bidang pekerjaan menuntut adanya e-Helpdesk di dalam organisasi (Akinnuwesi et al., 2014). Pembangunan suatu website yang dinamis dapat digunakan untuk mengembangkan e-Helpdesk yang dibutuhkan sebagai sistem dukungan teknis. Sedangkan sebuah website adalah kumpulan halaman web yang saling terkait dan biasanya disimpan di dalam komputer web server (Dean, 2018). Terdapat penelitian mengenai implementasi web server pada sistem reservasi yang mampu menawarkan pelayanan dengan informasi yang terperinci dan transparan dari pihak pengelola (Wiguna \& Alawiyah, 2019). Kemudian sistem yang dibangun menggunakan web programming sangat tepat untuk diterapkan pada perusahaan ritel (Mirawati et al., 2018). 
Penelitian ini bertujuan untuk mengembangkan pengetahuan yang sudah ada yang disebut dengan penelitian pengembangan (development research). Penelitian pengembangan diarahkan untuk mengatasi solusi dengan menemukan produk baru yang menekankan pada analisis sistem sebagai tahap identifikasi permasalahan sistem yang sudah ada. Selanjutnya dirancang sistem baru yang lebih baik sesuai dengan harapan pengguna (Muharto \& Ambarita, 2016). Sehingga diusulkan pengembangan suatu sistem dukungan teknis yaitu e-Helpdesk Support System berbasis web pada PT Akur Pratama.

\section{Metode Penelitian}

\subsection{Teknik Pengumpulan Data}

Pada penelitian ini menggunakan metode pengumpulan data primer yang melibatkan pengumpulan data dari sumber asli untuk tujuan spesifik penelitian (Sekaran \& Bougie, 2016). Sedangkan teknik pengumpulan data yang digunakan untuk pengembangan e-Helpdesk Support System di PT Akur Pratama (Mauliana et al., 2018) sebagai berikut:

1. Observasi, dilakukan pengamatan langsung di tempat riset yaitu PT Akur Pratama dengan mengamati sistem yang sedang berjalan untuk mendapatkan data yang dapat dijadikan sebagai bahan penelitian.

2. Wawancara, dilakukan wawancara dengan IT Support dan Service Desk maupun karyawan internal lainnya pada PT Akur Pratama guna mengetahui kebutuhan dari manajemen dukungan teknis.

3. Studi pustaka, melakukan tinjauan literatur dengan mengumpulkan dan mempelajari beberapa jurnal maupun buku-buku yang menunjang serta berkaitan dengan pengembangan $e$ Helpdesk Support System menggunakan pemrograman web.

\subsection{Metode Pengembangan Sistem}

Metode pengembangan e-Helpdesk

Support System menggunakan model Waterfall pada pemograman web yang terbagi menjadi beberapa tahapan (Hariyanti \& Wiguna, 2019) diantaranya:

1. Analisis, menganalisa semua kebutuhan yang diperlukan guna menentukan solusi perangkat lunak yang akan digunakan sebagai proses komputerisasi sistem.
2. Desain, mendefinisikan kebutuhan pengembangan sistem yaitu rancangan database menggunakan ERD dan LRS, serta software architecture dengan UML.

3. Implementasi, bahasa pemrograman yang akan digunakan yaitu pemrograman web (PHP, Java Script, HTML, dan CSS) dengan hasil penerapannya yang ditampilkan melalui user interface.

4. Pengujian, proses pengujian menggunakan black box testing untuk menguji input dari sistem terhadap output yang diharapan.

5. Support, beberapa upaya mengantisipasi perkembangan sistem terkait dengan hardware dan software yang akan digunakan meliputi pengoperasian program pada lingkungannya serta pemeliharaan sistem.

\section{Hasil dan Pembahasan}

Hasil pada penelitian ini merujuk pada penelitian terapan (applied reserch) yang bermanfaat untuk memecahkan permasalahan praktis. Kemudian dilakukan pengembangan pengetahuan yang sudah ada yang disebut dengan penelitian pengembangan (development research) yang diarahkan untuk mengatasi solusi dengan menemukan sistem yang baru. Penelitian ini menekankan pada analisis sistem hingga dirancangnya sistem baru yang lebih baik sesuai dengan harapan pengguna.

\subsection{Analisis}

\subsubsection{Tahapan Analisis}

Spesifikasi kebutuhan dari $e$ Helpdesk Support System yang akan dibangun antara lain:

\section{A. Halaman User Client (Karyawan Internal)}

Terdapat beberapa halaman dari eHelpdesk Support System yang dapat diakses oleh User Client, diantaranya:

A1. User Client dapat melakukan proses login sesuai dengan hak aksesnya yaitu dengan memasukkan alamat email dan password.

A2. User Client dapat mengajukan komplain berupa ticket support atas keluhannya perangkat kerja IT yang digunakannya.

A3. User client dapat melakukan proses logout untuk keluar dari sistem. B. Halaman IT Support (Teknisi \& IT
Agent) 
Terdapat beberapa halaman dari eHelpdesk Support System yang dapat diakses oleh IT Support, diantaranya:

B1. IT Support dapat melakukan proses login sesuai dengan hak aksesnya yaitu dengan memasukkan alamat email dan password.

B2. IT Support dapat mengangani maupun merespon ticket support yang diajukan sebelumnya atau didapatkan dari User Client.

B3. IT Support bisa memeriksa rincian dari data divisi client.

B4. IT Support bisa memeriksa rincian dari data User Client.

B5. IT Support dapat melakukan proses logout untuk keluar dari sistem.

\section{Halaman Service Desk (Adm.} Helpdesk)

Terdapat beberapa halaman dari eHelpdesk Support System yang dapat diakses oleh Service Desk, diantaranya:

C1. Service Desk dapat melakukan login sesuai dengan hak aksesnya yaitu dengan memasukkan alamat email dan password.
C2. Service Desk dapat mengelola ticket support dan menugaskan (assign) IT Support.

C3. Service Desk dapat mengelola data divisi client.

C4. Service Desk dapat mengelola data User Client beserta hak aksesnya.

C5. Service Desk dapat mengelola data IT Support beserta hak aksesnya.

C6. Service Desk dapat melakukan generate dan merekap laporan sesuai dengan tanggal yang ditentukan.

C7. Service Desk dapat melakukan logout untuk keluar dari sistem.

\subsubsection{Use Case Diagram}

Digambarkan use case diagram sesuai dengan yang terkait pada proses bisnis utama sistem dari kebutuhan $e-$ Helpdesk Support System yang akan dikembangkan sebagai berikut:

1. Use Case Diagram User Client

Dialog atau interaksi antara User Client dengan e-Helpdesk Support System terlihat pada Gambar 1.

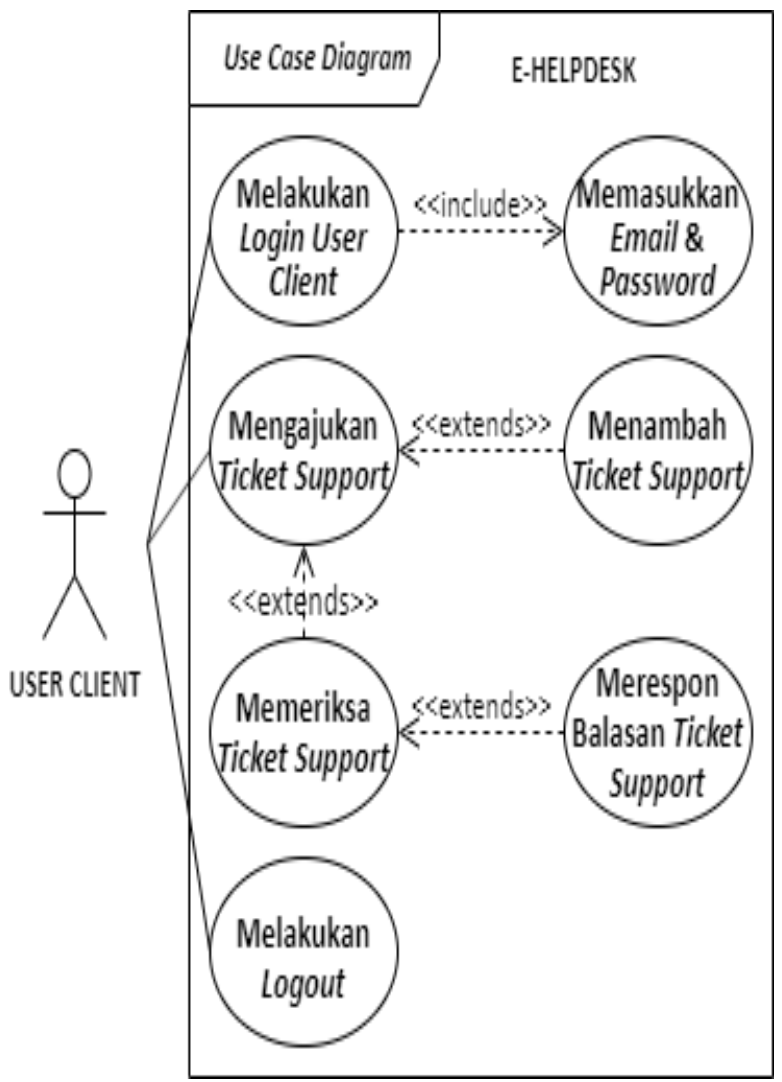

Gambar 1. Use Case Diagram User Client 
Pada Gambar 1 menunjukkan interaksi antara User Client dengan sistem yaitu melakukan login, mengajukan ticket support, dan melakukan logout sistem.
2. Use Case Diagram IT Support

Interaksi antara IT Support (Teknisi dan IT Agent) dengan e-Helpdesk Support System dapat dilihat pada Gambar 2.

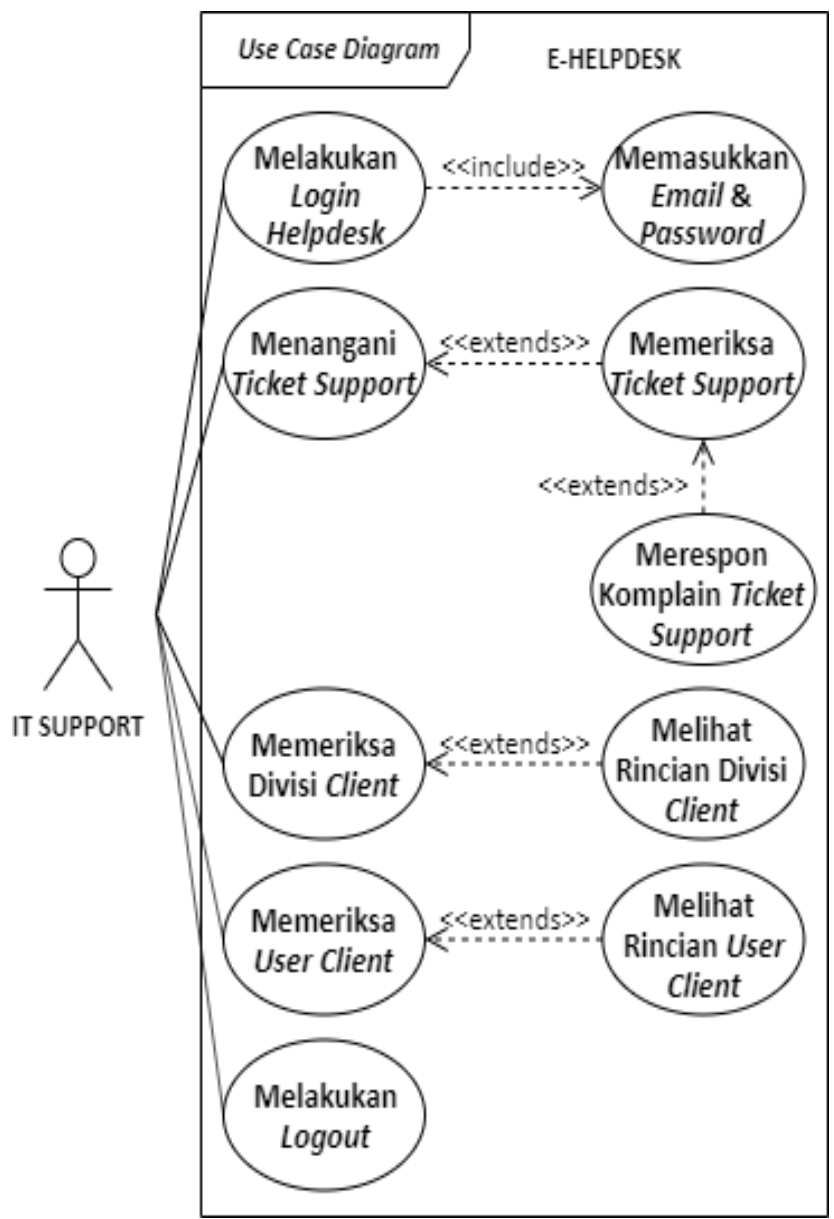

Gambar 2. Use Case Diagram IT Support

Pada Gambar 2 menunjukkan interaksi IT Suppport dengan sistem yaitu melakukan login, menangani ticket support, memeriksa divisi client, memeriksa user client, dan melakukan logout.
3. Use Case Diagram Service Desk Dialog atau interaksi antara Service Desk dengan e-Helpdesk Support System ditunjukkan pada Gambar 3. 


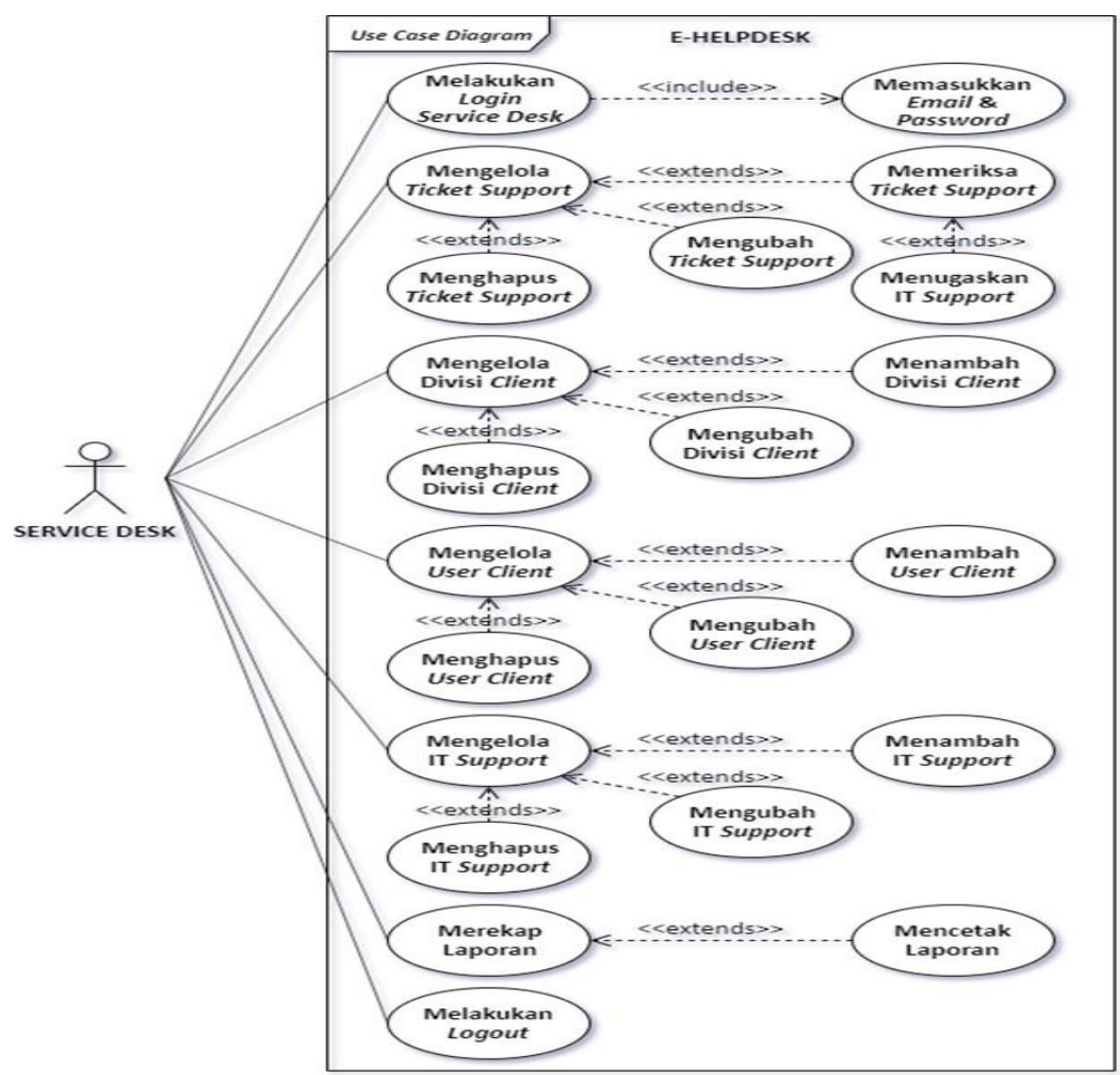

Gambar 3. Use Case Diagram Service Desk

Pada Gambar 3 menunjukkan interaksi antara Service Desk dengan e-Helpdesk Support System yaitu melakukan login, mengelola ticket support, mengelola divisi client, mengelola User Client, mengelola IT Support, merekap laporan, hingga melakukan logout.

\subsubsection{Activity Diagram}

Pada bagian ini diuraikan mengenai kegiatan-kegiatan yang dapat dilakukan oleh pengguna dengan e-Helpdesk Support
System yang sedang dirancang. Terdapat tiga tipe pengguna sistem mulai dari User Client, IT Support (Teknisi dan IT Agent), hingga Service Desk dengan beberapa aktivitasnya yang dapat dijelaskan sebagai berikut:

1. Acivity Diagram User Client

Beberapa aktivitas atau kegiatan yang dapat dilakukan oleh User Client dengan e-Helpdesk Support System seperti melakukan login, mengajukan ticket support, serta melakukan logout. 


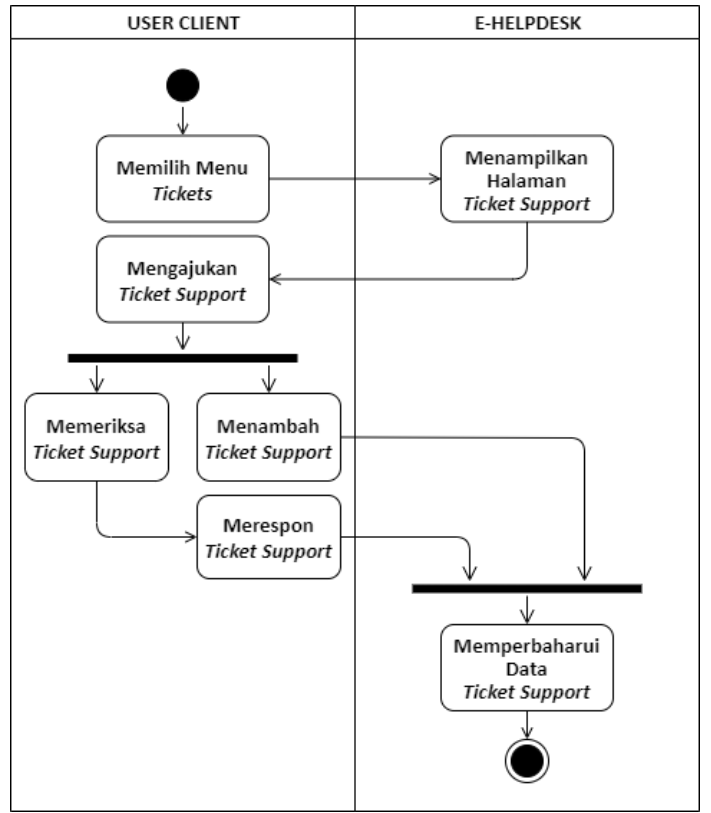

\section{Gambar 4. Activity Diagram Mengajukan Ticket Support}

Pada Gambar 4 merupakan kegiatan atau aktivitas yang dilakukan oleh User Client dalam mengajukan komplain berupa ticket support atas keluhan perangkat kerjanya melalui e-Helpdesk Support System.

2. Acivity Diagram IT Support
Beberapa aktivitas atau kegiatan yang dapat dilakukan oleh IT Support baik Teknisi maupun IT Agent dengan eHelpdesk Support System yaitu melakukan login, menangani ticket support, memeriksa divisi client, memeriksa user client, dan melakukan logout.

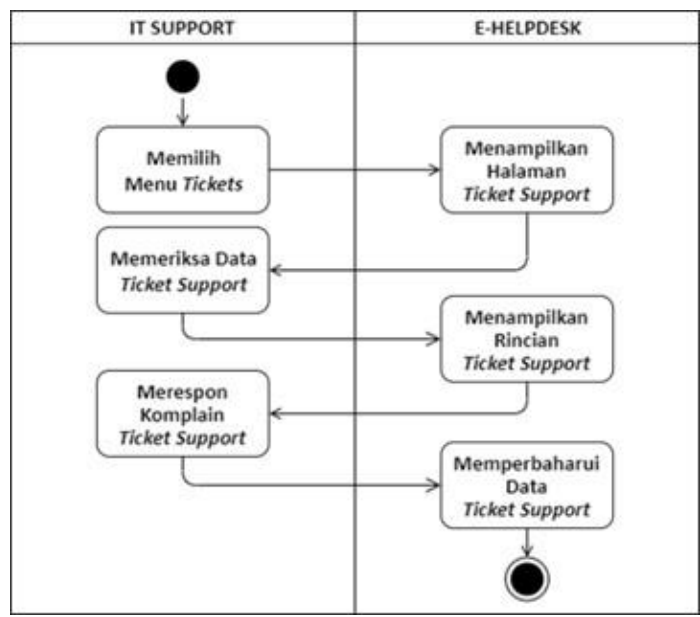

\section{Gambar 5. Activity Diagram Menangani Ticket Support}

Pada Gambar 5 menunjukkan aktivitas IT Support dalam merespon atau menangani ticket support yang diajukan sebelumnya yang didapatkan dari User Client.

3. Acivity Diagram Service Desk

Terdapat beberapa aktivitas yang dapat dilakukan oleh Service Desk terhadap e-
Helpdesk Support System mulai dari melakukan login, mengelola ticket support, mengelola divisi client, mengelola User Client, mengelola IT Support, merekap laporan, hingga melakukan logout. 


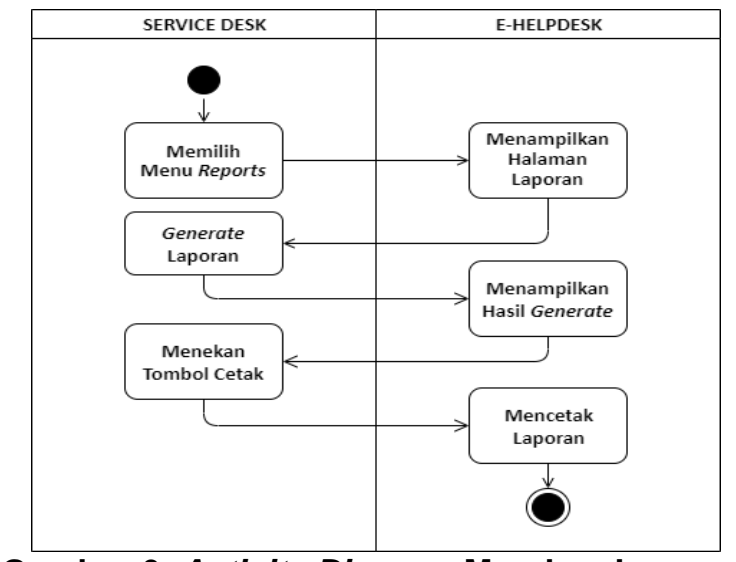

\section{Gambar 6. Activity Diagram Merekap Laporan}

Pada Gambar 6 menunjukkan kegiatan Service Desk dalam merekap laporan ticket support dengan melakukan generate dan mencetak laporan.

\subsection{Desain}

Pada tahap desain digambarkan perancangan database atau basis data menggunakan Entiry Relationship Diagram (ERD) untuk memodelkan struktur data dengan menggambarkan relasi antar entitas beserta masing-masing atributnya.

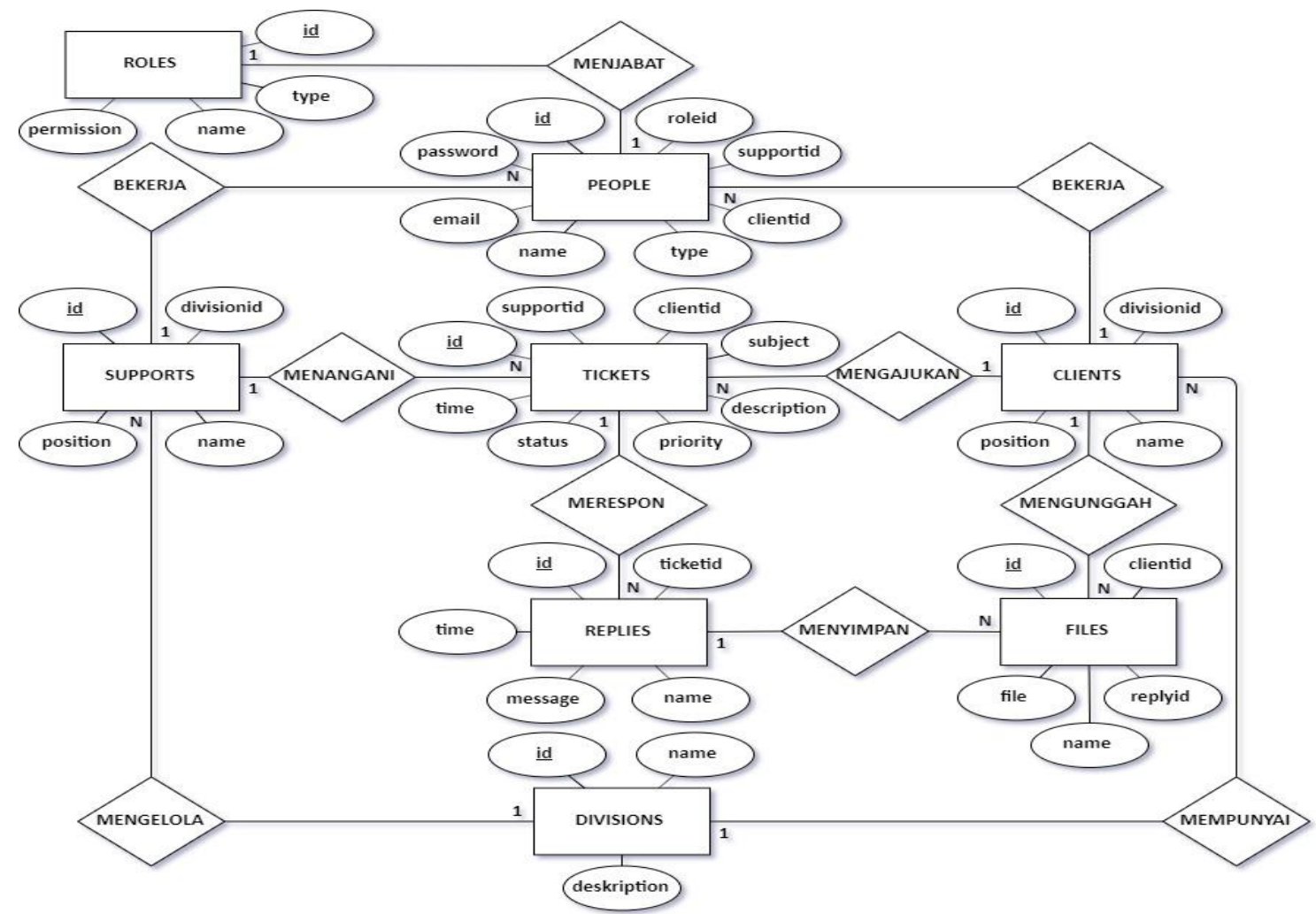

Gambar 7. ERD e-Helpdesk Support System

Pada Gambar 7 menunjukkan data entitas yang dikelola, disimpan, dan digunakan melalui basis data helpdesk dengan penjelasan relasi antar entitasnya sebagai berikut:

1. Relasi satu entitas pengguna (people) menjabat satu entitas hak akses (roles).
2. Relasi banyak entitas people bekerja sebagai satu entitas User Client (clients).

3. Relasi banyak entitas people bekerja sebagai satu entitas IT Support ataupun Service Desk (supports). 
4. Relasi satu entitas User Client (clients) dapat mengajukan banyak entitas tickets yang mewakili ticket support.

5. Relasi satu entitas User Client (clients) dapat mengunggah banyak files.

6. Relasi banyak entitas replies dapat merespon satu entitas ticket support (tickets).

7. Relasi satu entitas balasan (replies) menyimpan banyak entitas files.

8. Relasi satu entitas divisi (divisions) mempunyai banyak entitas clients.

9. Relasi satu entitas IT Support (supports) dapat menangangani banyak entitas tickets.

10. Relasi satu entitas Service Desk (supports) dapat mengelola banyak entitas divisions.

\subsection{Implementasi}

A. User Interface

Menampilkan antarmuka pengguna dari e-Helpdesk Support System yang telah dibangun.

1. Antarmuka User Client

Tampilan User Client dalam mengajukan ticket support terdapat pada Gambar 8.

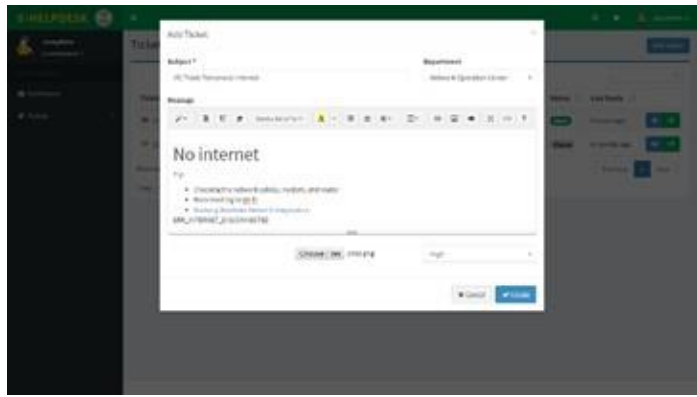

Gambar 8. Tampilan Mengajukan Ticket Support

\section{Antarmuka IT Support}

Halaman IT Support dalam menangani ticket support dari User Client ditunjukkan pada Gambar 9.

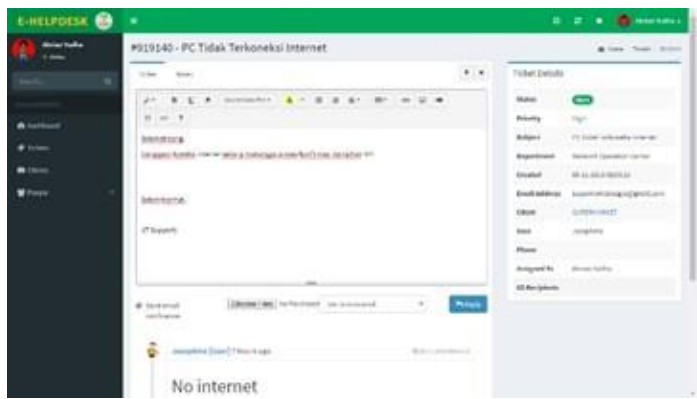

Gambar 9. Tampilan Menangani Ticket Support

\section{Antarmuka Service Desk}

Halaman Service Desk dalam merekap laporan dengan tampilannya yang dapat dilihat pada Gambar 10.

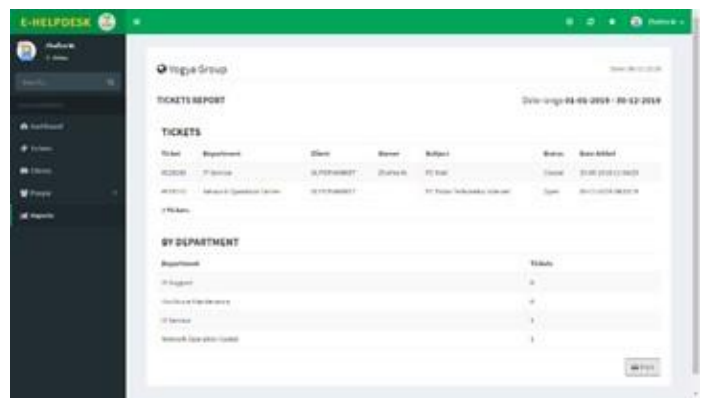

Gambar 10. Tampilan Merekap Laporan

B. Spesifikasi Dokumen Sistem Usulan

Beberapa bentuk dokumen yang terlibat pada implementasi sistem yaitu:

1. Dokumen Input Ticket Support (TS)

Nama Dokumen : Formulir TS

Fungsi : Mengajukan komplain

Sumber : User Client

Tujuan : : IT Support

Media : Web Pages

Jumlah : 1 halaman

Frekuensi : Setiap komplain

2. Dokumen Output Ticket Support (TS)

Nama Dokumen : Laporan TS

Fungsi : Merekap laporan

Sumber : Service Desk

Tujuan : IT Manager

Media : Berkas PDF \& Kertas

Jumlah $\quad: 2$ rangkap

Frekuensi : Setiap bulan

\subsection{Pengujian}

Sistem yang dikembangkan diujikan menggunakan black box testing.

1. Pengujian Sistem User Client

Proses pengujian sistem pada menu User Client dapat dilihat pada Tabel 1.

Tabel 1. Pengujian Sistem User Client

\begin{tabular}{|c|l|l|l|l|}
\hline No. & Skenario & \multicolumn{1}{|c|}{ Input } & Next Stage & Hasil \\
\hline 1 & $\begin{array}{l}\text { Login User } \\
\text { Client }\end{array}$ & $\begin{array}{l}\text { Email, } \\
\text { Password, \& } \\
\text { Sign In. }\end{array}$ & $\begin{array}{l}\text { User Client } \\
\text { Dashboard }\end{array}$ & Valid \\
\hline 2 & $\begin{array}{l}\text { Mengajuka } \\
\text { n Ticket } \\
\text { Support }\end{array}$ & $\begin{array}{l}\text { Subject, } \\
\text { Department, } \\
\text { Message, } \\
\text { Priority, \& } \\
\text { Create. }\end{array}$ & $\begin{array}{l}\text { Updating } \\
\text { Database }\end{array}$ & Valid \\
\hline 3 & $\begin{array}{l}\text { Logout } \\
\text { User Client }\end{array}$ & Sign Out & $\begin{array}{l}\text { Keluar dari } \\
\text { sistem }\end{array}$ & Valid \\
\hline
\end{tabular}


2. Pengujian Sistem IT Support

Proses pengujian sistem pada menu IT

Support dapat dilihat pada Tabel 2.

Tabel 2: Pengujian Sistem IT Support

\begin{tabular}{|c|l|l|l|l|}
\hline No. & Skenario & \multicolumn{1}{|c|}{ Input } & Next Stage & Hasil \\
\hline 1 & $\begin{array}{l}\text { Login IT } \\
\text { Support }\end{array}$ & $\begin{array}{l}\text { Email, } \\
\text { Password, \& } \\
\text { Sign In. }\end{array}$ & $\begin{array}{l}\text { IT Support } \\
\text { Dashboard }\end{array}$ & Valid \\
\hline 2 & $\begin{array}{l}\text { Menangani } \\
\text { Ticket } \\
\text { Support }\end{array}$ & $\begin{array}{l}\text { Response, } \\
\text { Status, \& } \\
\text { Reply. }\end{array}$ & $\begin{array}{l}\text { Updating } \\
\text { Database }\end{array}$ & Valid \\
\hline 3 & $\begin{array}{l}\text { Memeriksa } \\
\text { Divisi } \\
\text { Client }\end{array}$ & $\begin{array}{l}\text { View Divisi } \\
\text { Client }\end{array}$ & $\begin{array}{l}\text { Halaman } \\
\text { Divisi Client }\end{array}$ & Valid \\
\hline 4 & $\begin{array}{l}\text { Memeriksa } \\
\text { User Client }\end{array}$ & $\begin{array}{l}\text { View User } \\
\text { Client }\end{array}$ & $\begin{array}{l}\text { Halaman } \\
\text { User Client }\end{array}$ & Valid \\
\hline 5 & $\begin{array}{l}\text { Logout IT } \\
\text { Support }\end{array}$ & Sign Out & $\begin{array}{l}\text { Keluar dari } \\
\text { sistem }\end{array}$ & Valid \\
\hline
\end{tabular}

3. Pengujian Sistem Service Desk

Proses pengujian sistem pada menu Service Desk dapat dilihat pada Tabel 3.

Tabel 3: Pengujian Sistem Service Desk

\begin{tabular}{|c|l|l|l|l|}
\hline No. & Skenario & \multicolumn{1}{|c|}{ Input } & Next Stage & Hasil \\
\hline 1 & $\begin{array}{l}\text { Login } \\
\text { Service } \\
\text { Desk }\end{array}$ & $\begin{array}{l}\text { Email, } \\
\text { Password, \& } \\
\text { Sign In. }\end{array}$ & $\begin{array}{l}\text { Service } \\
\text { Desk } \\
\text { Dashboard }\end{array}$ & Valid \\
\hline 2 & $\begin{array}{l}\text { Mengelola } \\
\text { Ticket } \\
\text { Support }\end{array}$ & $\begin{array}{l}\text { Data Ticket } \\
\text { Support \& } \\
\text { Create. }\end{array}$ & $\begin{array}{l}\text { Updating } \\
\text { Database }\end{array}$ & Valid \\
\hline 3 & $\begin{array}{l}\text { Mengelola } \\
\text { Divisi Client }\end{array}$ & $\begin{array}{l}\text { Data Divisi } \\
\text { Client \& } \\
\text { Create. }\end{array}$ & $\begin{array}{l}\text { Updating } \\
\text { Database }\end{array}$ & Valid \\
\hline 4 & $\begin{array}{l}\text { Mengelola } \\
\text { User Client }\end{array}$ & $\begin{array}{l}\text { Data User } \\
\text { Client, } \\
\text { Create. }\end{array}$ & $\begin{array}{l}\text { Updating } \\
\text { Database }\end{array}$ & Valid \\
\hline 5 & $\begin{array}{l}\text { Mengelola } \\
\text { IT Support }\end{array}$ & $\begin{array}{l}\text { Data IT } \\
\text { Support, } \\
\text { Create. }\end{array}$ & $\begin{array}{l}\text { Updating } \\
\text { Database }\end{array}$ & Valid \\
\hline 6 & $\begin{array}{l}\text { Merekap } \\
\text { Laporan }\end{array}$ & $\begin{array}{l}\text { Client, Start } \\
\text { Date, \& End } \\
\text { Date. }\end{array}$ & $\begin{array}{l}\text { Ticket } \\
\text { Support } \\
\text { Reports }\end{array}$ & Valid \\
\hline 7 & $\begin{array}{l}\text { Logout } \\
\text { Service } \\
\text { Desk }\end{array}$ & $\begin{array}{l}\text { Submit Sign } \\
\text { Out }\end{array}$ & $\begin{array}{l}\text { Keluar dari } \\
\text { sistem }\end{array}$ & Valid \\
\hline
\end{tabular}

\section{Penutup}

\subsection{Kesimpulan}

Dari hasil analisa dan pembahasan penelitian e-Helpdesk Support System dapat diambil kesimpulan sebagai berikut:

1. Sistem yang dibangun mampu menampung komplain dari User Client atau karyawan internal perusahaan sehingga memudahkan proses pengajuan berbagai permasalahan teknis dari sistem operasional kerjanya.

2. E-Helpdesk Support System membantu pihak manajemen dalam melakukan efisiensi biaya operasional serta mempercepat penanganan teknis dari permasalahan sistem oleh IT Support.

3. E-Helpdesk Support System berhasil dibangun menggunakan pemrograman web dengan fitur assignment IT Support beserta perekapan laporan ticket support oleh Service Desk di PT Akur Pratama.

\subsection{Saran}

Solusi kelemahan sistem yang dibangun dari aspek manajerial, teknis sistem, dan penelitian bagi pembahasan selanjutnya antara lain:

1. Pada e-Helpdesk Support System dapat ditambahkan fitur online chatting yang memudahkan interaksi antar pengguna.

2. Penerapan e-Helpdesk Support System bisa dilengkapi dengan remote admin untuk mengontrol perangkat User Client dari jarak jauh guna mempercepat penanganan teknis.

3. E-Helpdesk Support System dapat dikembangkan dengan aplikasi mobile untuk melengkapi kebutuhan Service Desk dalam memantau IT Support.

\section{Referensi}

Akinnuwesi, B., Enikuomehin, O., Uzoka, F.M., Onwudike, O., Osamiluyi, A., \& Aribisala, B. (2014). Electronic helpdesk support system in tertiary institutions in developing countries. International Journal of Computer and Information Technology, 3, 1280-1291.

Beisse, F. (2014). A guide to computer user support for help desk and support specialists. Nelson Education.

Dean, J. (2018). web programming with html5, css, and javascript. Jones \& Bartlett Learning.

Hariyanti, I., \& Wiguna, W. (2019). Perbandingan Metode Weighted Product dengan Simple Additive Weighting untuk Evaluasi Kinerja Kasir. JURNAL RESPONSIF: Riset Sains \& Informatika, 1(1), 33-45.

Mauliana, P., Wiguna, W., \& Widyaman, D. (2018). Sistem Pendukung Keputusan Evaluasi Kinerja Pramuniaga Toserba Yogya Ciwalk Menggunakan Metode Weighted Product. Infotronik: Jurnal Teknologi Informasi Dan Elektronika, 3(2), 85-94.

Mirawati, M., Hikmah, A. B., \& Wiguna, W. (2018). Sistem Penunjang Keputusan Penilaian Kinerja Kasir Lotte Mart Menggunakan Metode Weighted 
Product. IJCIT (Indonesian Journal on Computer and Information Technology), 3(2).

Muharto \& Ambarita, A. (2016). Metode Penelitian Sistem Informasi: Mengatasi Kesulitan Mahasiswa Dalam Menyusun Proposal Penelitian. Deepublish. Yogyakarta.

Sekaran, U., \& Bougie, R. (2016). Research methods for business: A skill building approach. John Wiley \& Sons.

Stair, R. M. (2017). Fundamentals of Information Systems. Course Technology.

Wiguna, W., \& Alawiyah, T. (2019). Sistem Reservasi Paket Wisata Pelayaran Menggunakan Mobile Commerce di Kota Bandung. Jurnal VOI (Voice Of Informatics), 8(2). 